\title{
Os atendimentos de Crianças e Adolescentes vítimas de abuso sexual: Uma análise na Comarca de Júlio De Castilhos/RS
}

The care of Children and Adolescents victims of sexual abuse: An analysis in the Júlio De

\author{
Castilhos/RS region
}

La atención a niños, niñas y adolescentes víctimas de abuso sexual: Un análisis en la región Júlio De Castilhos/RS

\author{
Natália da Rocha Santos \\ ORCID: https://orcid.org/0000-0003-3779-5188 \\ Universidade de Cruz Alta, Brasil \\ E-mail: natalia.darocha@ hotmail.com \\ Angela Simone Pires Keitel \\ ORCID: https://orcid.org/0000-0002-0516-0623 \\ Universidade de Cruz Alta, Brasil \\ E-mail: angelakeitel@unicruz.edu.br \\ Vanessa Steigleder Neubauer \\ ORCID: https://orcid.org/0000-0001-6182-3455 \\ Universidade de Cruz Alta, Brasil \\ E-mail: vneubauer@unicruz.edu.br \\ Deivid Jonas Silva da Veiga \\ ORCID: https://orcid.org/0000-0002-1625-0560 \\ Escola Superior do Ministério Público, Brasil \\ E-mail: deividveiga96@gmail.com \\ Aline Antunes Gomes \\ ORCID: https://orcid.org/0000-0003-4845-5664 \\ Universidade de Cruz Alta, Brasil \\ E-mail: algomes@unicruz.edu.br \\ Ieda Márcia Donati Linck \\ ORCID: https://orcid.org/0000-0001-5984-4003 \\ Universidade de Cruz Alta, Brasil \\ E-mail: imdlinck@gmail.com
}

\begin{abstract}
Resumo
As crianças e adolescentes são as maiores vítimas de violência, isso porque estão em condição especial de desenvolvimento e na maioria dos episódios são vítimas de violência praticada por familiares ou por pessoas que deveriam protegê-las. A natureza das consequências são variáveis, pois vai depender muito do tipo de atendimento que essa vítima recebeu e se continua recebendo ao longo da vida, haja vista que podem existir consequências a curto, médio e a longo prazo. Assim, o presente artigo científico trata de uma verificação relativamente a aplicação do protocolo previsto na Lei 13.431/2017, Lei da Escuta Protegida, nos atendimentos de criança e adolescentes vítimas de abuso sexual, no Município de Júlio de Castilhos/RS. No que tange a metodologia utilizada no presente trabalho, trata-se de pesquisa qualitativa bibliográfica, uma vez que se utilizou doutrinas, reportagens e artigos veiculados em jornais, revistas jurídicas e científicas e em ambiente virtual (internet), bem como realizou-se pesquisa de campo a qual buscou analisar se havia a implementação de um protocolo de atendimento destinado a crianças e adolescentes vítimas de abuso sexual, junto ao órgão Municipal. Assim, os resultados demonstram, a partir dos colhidos, que não há qualquer previsão legal sobre essa normatização no Município de Júlio de Castilhos, tampouco existe um protocolo de atendimento com os fluxos desses atendimentos, o que faz com que os atendimentos não sejam realizados de acordo com o que preconiza a Lei. 13.431/2017.
\end{abstract}

Palavras-chave: Atendimento; Infantojuvenil; Normatização; Protocolo; Violência sexual.

\begin{abstract}
Children and adolescents are the main victims of violence, because they are in a special condition of development and in most episodes they are victims of violence practiced by relatives or people who should protect them. The nature of the consequences are variable because it will depend very much on the type of care that this victim received and continues to receive throughout life, given that there may be consequences in the short, medium and long term. Thus, this scientific article deals with a verification regarding the application of the protocol provided for in Law 13.431/2017, the Protected Listening Law, in the care of children and adolescents victims of sexual abuse, in the
\end{abstract}


Municipality of Júlio de Castilhos/RS. Regarding the methodology used in the present study, this is a qualitative bibliographical research, since it used doctrines, articles and articles published in newspapers, legal and scientific journals and in virtual environment (internet), as well as field research was carried out, which sought to analyze whether the implementation of a protocol of care for children and adolescents victims of sexual abuse was carried out at the Municipal Office. Thus, the results demonstrate, from the collected data, that there is no legal prediction about this standardization in the Municipality of Júlio de Castilhos, nor does there exist a protocol of attendance with the flows of these services, which means that the attendances are not performed in accordance with the provisions of Law $13.431 / 2017$.

Keywords: Attendance; Child's-juveniles; Normalization; Protocol; Sexual violence.

\section{Resumen}

Los niños, niñas y adolescentes son las mayores víctimas de la violencia, porque se encuentran en una especial condición de desarrollo y en la mayoría de los episodios son víctimas de la violencia practicada por familiares o personas que deben protegerlos. La naturaleza de las consecuencias es variable, ya que dependerá mucho del tipo de atención que esta víctima recibió y sigue recibiendo a lo largo de la vida, dado que puede haber consecuencias a corto, medio y largo plazo. Así, este artículo científico trata de una verificación sobre la aplicación del protocolo previsto en la Ley 13.431/2017, Ley de Escucha Protegida, en la atención de niños, niñas y adolescentes víctimas de abuso sexual, en el Municipio de Júlio de Castilhos/RS. En cuanto a la metodología empleada en el presente trabajo, se trata de una investigación bibliográfica cualitativa, ya que se utilizaron doctrinas, informes y artículos publicados en periódicos, revistas jurídicas y científicas y en un entorno virtual (internet), así como se realizó la investigación. De campo que buscó analizar si existió la implementación de un protocolo de atención a niños, niñas y adolescentes víctimas de abuso sexual, con la agencia Municipal. Así, los resultados demuestran, con base en los datos recolectados, que no existe una disposición legal para esta estandarización en el Municipio de Júlio de Castilhos, ni existe un protocolo de servicio con los flujos de estos servicios, lo que significa que los servicios no se realizan. oportunamente, de acuerdo con lo establecido en la Ley. 13.431/2017.

Palabras clave: Servicio; Infanto juvenil; Estandarización; Protocolo; Violencia sexual.

\section{Introdução}

O abuso sexual, por envolver inúmeras circunstâncias, é um tema revestido de caráter altamente complexo. Isso porque, ao envolver crianças e adolescentes, verifica-se que estas não possuem capacidade de entender o significado do contato sexual e discernimento para não consentir com essas atitudes. Os registros do Sistema de Informação de Agravos de Notificação (SINAN) apontaram em 2014 que cerca de 89\% das vítimas são do sexo feminino e de escolaridade baixa. Desse percentual, $70 \%$ são crianças e adolescentes.

A cada 11 minutos uma pessoa é estuprada no Brasil, contudo se deduz que somente 10\% dos casos são registrados nos órgãos policiais, assim apontam os dados do SINAN. Já no Estado do Rio Grande do Sul, de 2010 a 2017, o SINAN indica o registro de 14.625 crimes de estupro, observando-se que 2.306 das ocorrências foram no ano de 2017.

A violência sexual torna-se ainda mais complexa para a vítima que é abusada por pessoas que estão comumente convivendo ao seu redor e que, na maioria das vezes, são as que possuem o dever legal de lhes ampararem e garantirem os direitos fundamentais, visando protegê-las.

Nesse sentido, apontaram os dados do Anuário Brasileiro de Segurança Pública, indicando que aproximadamente 40\% dos estupradores dos casos envolvendo crianças faziam parte do quadro familiar próximo, sendo assim, componentes como o pai, padrasto, tio, irmão e avô.

A legislação brasileira tipifica diversas condutas que vão ao encontro ao respeito e zelo pela dignidade sexual, inclusive com redação específica para tratar dessa ocorrência contra os vulneráveis, onde estão situados as crianças e os adolescentes de até 14 anos. Além disso, conforme dispõe a Lei 8.072/90 (Lei dos Crimes Hediondos), tanto o estupro, quanto o estupro de vulnerável, se enquadram na condição hedionda que a referida Lei prevê. Dessa maneira, notoriamente verifica-se que o ordenamento jurídico está atento a essas práticas delituosas e por isso providenciou agravar-lhes a reprovação.

Considerando a condição da violência sexual ser capaz de atingir todos os ciclos de vida da vítima e, inclusive, causar traumas físicos e psíquicos, visíveis e invisíveis, e de tamanha profundidade, que em alguns casos nunca chegam a ser 
diminuídos, é de grande valia a positivação de um protocolo de atendimento que busque suavizar ou dar fim aos danos que essas agressões causaram nas vítimas, prestado imediatamente à ocorrência da violência e, também, a longo prazo.

Nessa vertente, a Lei 13.431/2017 estabeleceu o sistema de garantias de direitos da criança e do adolescente vítima ou testemunha de violência. No artigo 27, está determinado que incumbe aos Estados, ao Distrito Federal e aos Municípios proceder a normatização de mecanismos de proteção, no prazo de até 180 dias, a contar de 05 de abril de 2018.

Inseridos no conceito "mecanismos de proteção" tem-se a possibilidade de previsão de protocolos e fluxos de atendimento interinstitucional. Assim, indaga-se: o Município de Júlio de Castilhos, tem observado o princípio da prioridade absoluta à criança e ao adolescente, disposto no artigo 227 da Constituição Federal e no artigo $4^{\circ}$, caput, e parágrafo único, alínea c, da Lei no 8.069/90 (Estatuto da Criança e do Adolescente), no que tange ao cumprimento da determinação legal, predefinindo um protocolo de tratamento padronizado visando amenizar os traumas de crianças e adolescentes vítimas de violência sexual? Caso não tenha atentado, qual a forma adequada para que esse mecanismo seja implementado?

Como hipótese norteadora da pesquisa tem-se que o Município de Júlio de Castilhos, apesar de possuir equipe profissional disponível para desenvolver um procedimento padrão almejando reduzir os traumas que os abusos sexuais deixaram em crianças e adolescentes não regulamentou a previsão do art. 27 da Lei 13.431/17. Face a ausente da concretização teórica de um protocolo de atendimento, a rede de apoio, juntamente dos órgãos envolvidos, encaminhava as vítimas incialmente ao Conselho Tutelar para acompanhamento na realização do exame de corpo de delito (se consentido), e colhendo depoimento da vítima somente após a denúncia junto a Delegacia de Polícia

Diante do questionamento, tratou-se de verificar se o Município de Júlio de Castilhos aplicou o protocolo previsto na Lei 13.431/2017 nos atendimentos de criança e adolescentes vítimas de abuso sexual e, em caso de não observância do diploma legal, como essa implementação poderia ocorrer.

\section{Metodologia}

A metodologia empregada na busca dessa pesquisa foi a qualitativa bibliográfica. As pesquisas realizadas sob a ótica qualitativa imergem em níveis subjetivos a compreensão dos aspectos intrínsecos da história e da realidade social trazendo à tona uma visão subjetiva de valores, crenças e até mesmo ações relacionadas a formação e atuação dos sujeitos em sociedade (Minayo, 1983, p. 239-262).

Assim foi elaborada pesquisas com base em doutrinas, reportagens e artigos veiculados em jornais, revistas jurídicas e científicas e em ambiente virtual (internet), da área relacionada, buscando também analisar se há a implementação de um protocolo de atendimento destinado a crianças e adolescentes vítimas de abuso sexual, junto ao órgão Municipal, o que denota que seu exame se deu mediante a interpretação desse problema na sociedade e posterior verificação de métodos que trabalham com as situações derivadas da violência sexual.

Sendo assim, objetivando encontrar resultados através de diligências, como hipóteses ou até mesmo teorias, fez-se uso do método hipotético-dedutivo. O referido método igualmente conhecido como "método de tentativas e eliminação de erros", busca prever e corrigir possíveis erros a surgir no curso da pesquisa (Popper, 1975). Observa-se que também foi realizada uma abordagem descritiva, com propósito de descrever o fenômeno que o trabalho envolve e verificar se as crianças e adolescentes já podem contar com um atendimento diferenciado, oferecido pelo Município de Júlio de Castilhos/RS. 


\section{Resultados e Discussão}

\section{Evolução legislativa dos Direitos da Criança e do Adolescente}

Os direitos das crianças e dos adolescentes estão previstos no Estatuto da Criança e do Adolescente, porém é preciso abordar o avanço histórico percorrido até se conquistar essas garantias.

De acordo com Rossato, Lépore e Sanches (2014, p.50), as crianças e adolescentes possuem atualmente uma série de direitos e garantias, infelizmente, em decorrência de um período histórico em que não estavam amparados por qualquer legislação ou documento que pudesse, no mínimo, ser comparado a uma base normativa que lhes assegurassem proteção e cuidado. Isso não quer dizer que não existiam violações de garantias e direitos inerentes ao público infanto-juvenil antigamente. Muito pelo contrário, após anos sem despertar a preocupação do poder estatal, as medidas que existem recentemente, são uma maneira do Estado buscar compensar todo o período em que crianças e adolescentes não tinham qualquer visibilidade e atenção na sociedade.

Em sua obra, os referidos autores trazem o caso específico de Mary Ellen, o qual traduz, exatamente, como essas questões eram tratadas naquela época:

Em abril de 1874, Etta Wheeler - uma assistente social norte-americana - teve conhecimento de uma menina que sofria severos maus tratos por parte dos pais, apresentando queimaduras e cicatrizes aparentes, além de ser mantida em cárcere privado. Mary Ellen Wilson, de nove anos de idade, despertou o altruísmo de Etta, que tentou por todos os meios legais ajudar a criança, fazendo apelos à polícia, à igreja e ao judiciário, sempre recebendo a resposta de que entre pais e filhos não se deveria interferir. Etta, entretanto, não se deu por vencida, e procurou Henry Bergh, então Presidente da Sociedade Americana para a Prevenção de Crueldade contra os Animais, pois para ela, se não existiam leis que protegessem crianças, a solução seria recorrer à legislação de proteção aos animais, pois a criança não era menos que um cachorro ou um gato. (Rossato; Lépore \& Sanches, 2014)

Veja-se que, mesmo que o exemplo seja interpretado como um propulsor ao avanço e visibilidade de crianças e adolescentes na época de sua ocorrência, não se pode ignorar a gravidade em sua essência. Isto é, trata-se de violência praticada pelos pais contra uma criança, que mesmo sendo de conhecimento dos órgãos competentes, eles negavam-se em fornecer auxílio para que a infante saísse daquele meio de convivência usando do argumento que entre pais e filho não seria correto haver intervenções.

Frisa-se, ainda, que a única pessoa disposta a ajudar no caso, já tendo esgotado os meios que entendia como passíveis de prestar auxílio, teve de usar de uma analogia feita entre animais e seres humanos, na tentativa de demonstrar que, da mesma forma que os cachorros e gatos merecem amparo legal em prol de seus direitos básicos à vida, saúde, dignidade e proteção, crianças e adolescentes também deveriam fazer jus a essas garantias, mesmo que para isso fosse necessário a intervenção do Estado. Assim, pela importância do argumento defendido, vale destacar o pequeno trecho onde consta que "a criança não era menos que um cachorro ou um gato" (Rossato; Lépore \& Sanches, 2014).

Nesse contexto, é possível fazer destaque a linha tênue que paira sobre o exato momento da intervenção do Estado no poder familiar e quais atitudes podem os órgãos desenvolver. Conforme aponta Ramborger (2015, p.20), respeitados os limites de atuação do poder familiar, quando houver violação de direitos, observando o momento correto de atuação, o Estado deverá intervir aplicando medidas de proteção em favor da criança ou adolescente que está sendo lesada, no intuito de garantir seus direitos, tudo isso, de acordo com o caso em concreto. Nessa mesma linha Ramborger (2015, p.21) destaca: [...] "na falta, omissão ou abuso dos pais ou responsável pela criança e pelo adolescente serão aplicadas medidas de proteção a fim de evitar maiores danos na vida do menor."

Em síntese, apesar do poder familiar ter conferido a ele autonomia na criação e educação dos filhos, quando houver violação de direitos, o Estado estará "apto" a intervir naquele núcleo familiar, desde que feito com profissionalismo e respeito as peculiaridades de cada família e caso específico. 
Satisfeitas essas questões, adentrando-se na análise dos direitos e garantias fundamentais reservados à crianças e adolescentes no Brasil, pontua-se que se perfectibilizaram com a criação do Estatuto da Criança e do Adolescente, introduzido no ordenamento jurídico no ano de 1990.

Antes disso, diferentemente, vigorava no país o Código de Mello Mattos, constituído pelo Decreto 17.943 de 12 de outubro de 1927, o qual apesar de determinar, pioneiramente, que somente os maiores de 18 anos de idade poderiam sofrer sanções penais e serem encarcerados, conforme disposto no artigo 86 , era dirigido às crianças e adolescentes abandonados, encontrados em situações de riscos, ou classificados como desvirtuados na seara social, sendo todos intitulados de "menores". Por isso, a doutrina que regia o referido Código era a da Situação Irregular, ou seja, havia amparo legal visando crianças e adolescentes, porém, somente quando elas se encontrassem em determinadas circunstâncias irregulares (Neri \& Oliveira, 2010).

Maia (2010, [s.p]), relativamente a Doutrina da Situação Irregular, esclarece que “[...] suprimia-se a figura da família como parte integrante e necessária do desenvolvimento do menor, dando-se mais importância ao recolhimento dos infratores como forma de proteger a sociedade do que se dedicando a resolver a questão.”.

Nota-se que a atuação do Estado consubstanciava-se apenas nos efeitos dos problemas sociais envolvendo crianças e adolescentes, ignorando, mesmo que cientes, as causas que levavam a essas ocorrências.

Em continuidade, foi instituído o Código de Menores de 1979, sem introduzir grandiosas novidades, pois manteve a doutrina da Situação Irregular. Nesse documento, mediante a leitura do seu artigo $1^{\circ}$ era possível identificar, de modo geral, suas propostas e público alvo e na sequência, por meio do artigo $2^{\circ}$, os casos então considerados como situação irregular.

Assim, observa-se que a preocupação do Estado em relação à crianças e adolescentes resumia-se às hipóteses taxadas no artigo $2^{\circ}$ do Código de Menores de 1979, sendo a maioria delas casos em que já houvera a violação dos direitos básicos do ser humano, como é a situação de maus-tratos, risco de perigo moral, exploração em atividades correlacionadas aos bons costumes, ou, ainda, situações em que crianças e adolescentes figuravam como autores de atos infracionais.

Ainda sobre a referida doutrina da Situação Irregular, Ferreira e Doi ([2000?], p. 1) destacam:

[...] para essa doutrina, os menores apenas são sujeitos de direito ou merecem a consideração judicial quando se encontrarem em uma determinada situação, caracterizada como "irregular", e assim definida em lei. Havia uma discriminação legal quanto à situação do menor, somente recebendo respaldo jurídico aquele que se encontrava em situação irregular; os demais, não eram sujeitos ao tratamento legal.

Por sua vez, o Estatuto da Criança e do Adolescente (ECA), instituído por meio da Lei 8.069 de 13 de julho de 1990, respaldado por normas mundiais como a Convenção Internacional dos Direitos da Criança, aprovada na Assembleia Geral das Nações Unidas em 1989, representou um marco normativo, haja vista a concessão de garantias fundamentais à crianças e adolescentes, reconhecendo-os como sujeitos de direito e adotando como doutrina o Princípio da Proteção Integral.

No tocante a nomenclatura utilizada, Ishida (2019, p. 21) coloca que a justificativa para chamar-se "Estatuto", está vinculado ao fato que o referido termo expressa direitos. Ainda, outra razão que justifica a aversão em designar o documento como sendo um Código, é que esse vocábulo pode ser vinculado ao caráter punitivo, como por exemplo, o Código Penal. Finalizando, o autor diz: "Já estatuto exprime a ideia de lei, de decreto, regulamento, sendo um termo mais apropriado".

Referente a esse ganho histórico, ainda, houve a retirada do termo "menor" dos cadernos legislativos destinados a crianças e adolescentes, terminologia que passou a identificar essa classe (Perez \& Passone, 2010).

Para fins elucidativos, ressalta-se que, segundo o artigo $2^{\circ}$ do ECA, considera-se como criança a pessoa que possui até 12 anos de idade incompletos, e como adolescente aquela que se encontra na faixa etária dos 12 aos 18 anos.

O Princípio da Proteção Integral, previsto no artigo $1^{\circ}$ do ECA, visa garantir o enfrentamento de situações 
relacionadas a crianças e adolescentes como prioridade absoluta. Tal condição é proclamada com a Declaração Universal dos Direitos da Criança de 1959, documento que preceitua dez princípios basilares relativos à infância.

No Brasil, a positivação desse princípio ocorreu, incialmente, por meio da Constituição Federal de 1988, mais precisamente no artigo 227, conferindo ao público infanto-juvenil um novo "status", pois dessa maneira a visão de "menores" encontrados em situação irregular, abandonados, ou autores de atos infracionais, anteriormente intitulados "delinquentes", acabou sendo substituída por um conceito de sujeitos de direitos (Ferreira \& Dói, [2000?]).

Acompanhando essa análise, acrescenta-se:

A introdução pela Doutrina da Proteção Integral, dos conceitos jurídicos de criança e adolescente, norteadores do novo sistema brasileiro, aboliu com a discriminatória expressão menor que caracterizava o adolescente infrator e elidiu o anterior tratamento dispensado à infância, pois passa a conceber uma única infância sob a ótica dos direitos humanos apresentando nova conceituação metodológica e jurídica para o tema infância, operando a substituição do "subjetivismo pelo garantismo." (Pereira, 2000, p.16 apud Vargas, 2015, p. 24).

Em consonância com o entendimento, tem-se as considerações feitas por Rossato, Lépore e Sanches (2014, p.77):

[...] Não implica a proteção integral em mera proteção a todo custo, mas sim na consideração de serem a criança e adolescente sujeitos de direito, devendo as políticas públicas contemplar essa situação, proporcionando o reequilíbrio existente pela condição de serem pessoas em desenvolvimento, o que deverá ser levado em consideração na interpretação do Estatuto.

Importante destacar que a proteção integral assegura um mínimo às crianças e aos adolescentes sem o qual eles não poderiam sobreviver, garantindo-lhes os mesmos direitos fundamentais dos adultos, e um plus, conforme, aliás, encontra-se previsto no art. $3^{\circ}$ do Estatuto.

Portanto, o metaprincípio da proteção integral orienta a prescrição de direitos às pessoas em desenvolvimento, e impõe deveres à sociedade, de modo a consubstanciar um status jurídico especial às crianças e adolescentes.

Desse modo, o ECA, por seguir essa vertente de proteção, amparo e zelo absoluto por crianças e jovens, estabeleceu quatro linhas de atuação norteadoras do atendimento aos direitos desse público, quais sejam:

a. as políticas sociais básicas de caráter universal, como saúde, educação, alimentação, moradia, etc. (art. 87, item I);

b. as políticas e programas de assistência social (art. 87, item II), de caráter supletivo, para aqueles de que delas necessitem;

c. as políticas de proteção, que representam serviços especiais de atendimento médico e psicossocial às vítimas de negligência, maus-tratos, exploração, abuso e opressão (art. 87, item III); os serviços de identificação e localização de pais, responsáveis, crianças e adolescentes desaparecidos (art. 87, IV);

d. as políticas de garantias de direitos, que representam as entidades e os aparatos jurídicos e sociais de proteção dos direitos individuais e coletivos da infância e juventude (art. 87, item V). (Perez \& Passone, 2010)

Ademais, outro princípio orientador do direito da criança e do adolescente é o da Municipalização. Consoante as colocações de Amim, Santos e Moraes (2017, p.76), a Constituição Federal de 1988 em seus artigos 203 e 204 ampliou a atuação das políticas assistências, descentralizando as atribuições aos entes da federação quando necessárias as práticas de ações governamentais em âmbito de assistência social. Sendo assim, as execuções desses programas podem ser feitas pelos Estados e Municípios, e também por entidades beneficentes e de assistência social. Segundo autoras referidas, Amim, Santos e Moraes (2017, p.76):

Acrescenta-se que é mais simples fiscalizar a implementação e cumprimento das metas determinadas nos programas se o Poder Público estiver próximo, até porque reúne melhores condições de cuidar das adaptações necessárias à realidade local. Aqui está o importante papel dos municípios na realização das políticas públicas de abrangência social. [...] Risco social ou familiar em que se encontram crianças e adolescentes são mazelas produzidas pelo meio onde vivem. Cabe, portanto, ao meio resolvê-las e, principalmente, evitá-las. Mutatis mutandi é o mesmo princípio da 
responsabilidade civil: aquele que causa o dano deve repará-lo.

Assim, da leitura acima, e procedendo em uma análise panorâmica das situações históricas envolvendo a criança e ao adolescente já citadas, verifica-se que as normas internacionais foram fundamentais para ensejar o sistema jurídico que foi construído no Brasil, o qual, por meio do Estatuto da Criança e do Adolescente - ECA, ao menos na teoria, estabelece princípios que visam evitar a violação dos direitos de infantes e adolescentes através de políticas públicas voltadas para a educação, saúde, assistência social e observância aos requisitos essenciais a sobrevivência como alimentação e moradia.

Ademais, face a sua completude, o ECA trás, ainda, a previsão de programas de políticas assistenciais que cuidam do tratamento daquelas crianças e jovens que já tiveram as garantias e direitos individuais e coletivos violadas, sendo notório que buscou solucionar as questões sociais do público infanto-juvenil, incialmente, privilegiando os métodos preventivos de inflição aos direitos em detrimento daqueles que servem apenas como meio de remediar os danos já existentes, o que se traduz pela observância das linhas centrais do Princípio da Proteção Integral.

Assim, feita a análise do aspectos históricos envolvendo crianças e adolescentes, tanto, brevemente, no cenário mundial, como o caso específico ocorrido nos Estados Unidos, como a nível nacional, onde mencionou-se a situação antes de vigorar o Estatuto da Criança e do Adolescente e após a sua criação, passa-se a verificar a prática de violência contra crianças e jovens.

\section{A violência sexual praticada contra Crianças e Adolescentes}

Conquanto, ainda que legitimados por garantias constitucionais e consagrados por direitos respaldados em Estatuto exclusivo, conforme destacou-se no tópico acima, por vezes, os direitos das crianças e dos adolescentes são violados. Uma das formas dessa ocorrência, é por meio da violência.

Conforme o relatório A Familiar Face: Violence in the lives of children and adolescents (Um Rosto Familiar: A violência na vida de crianças e adolescentes), no ano de 2015, ocorreram em torno de 82 mil mortes de crianças e adolescentes, com idade entre 10 e 19 anos, em decorrência de violência, não só física, mas também disciplinar, doméstica, sexual, e no âmbito escolar, inclusive, pelo bullying. (Fundo das Nações Unidas para a Infância, 2017).

A Lei 13.431/2017, conhecida pela nomenclatura de Lei da Escuta Protegida, se ocupou em estabelecer o sistema de garantia de direitos da criança e do adolescente vítima ou testemunha de violência.

Da leitura do seu artigo $1^{\circ}$, é possível notar que a intenção da Lei, além de normatizar e organizar esse microssistema de proteção, também é de criar mecanismos de prevenção e coibição de violências contra jovens e crianças e estabelecer medidas assistenciais e de proteção àqueles que estão em situação de violência.

No artigo $2^{\circ}$, a norma supramencionada determina que a União, os Estados, o Distrito Federal e os Municípios serão responsáveis por desenvolver políticas integradas e coordenadas para assegurar que crianças e adolescentes tenham seus direitos respeitados em diversas searas, seja familiar, educacional ou social, e estejam resguardados de qualquer forma de discriminação, negligências e vulneráveis ao cometimento de violências.

A legislação em comento, trouxe especificamente no seu artigo $4^{\circ}$ as formas de violência por ela consideradas e das quais pretende oferecer proteção e amparo, preestabelecendo-as, de antemão, no início do texto legislativo com o intuito de deixar o leitor a par do seu entendimento. Nos termos de Cunha, Pinto e Souza (2019, p. 2155), “[...] esse art. $4^{\circ}$ não tipifica condutas criminais, mas apenas apresenta o conceito de violência que pode ser utilizado na interpretação da presente Lei e, mediante hermenêutica sistemática, de muitas outras, a exemplo o ECA."

Conforme se observa no inciso IV do artigo $4^{\circ}$ da Lei 13.431/2017, pioneiramente, tem-se a introdução da violência institucional no ordenamento jurídico brasileiro, entendida como aquela praticada pelas instituições integrantes da rede de 
apoio e proteção à criança e ao adolescente, mesmo que involuntariamente, quando atendem as vítimas sem utilizar todas as técnicas necessárias ao zelo pelos direitos e garantias que possuem, submetendo-as, assim, à revitimização, terminologia também introduzida pela legislação acima mencionada. (Digiácomo \& Digiácomo, 2018).

Tecendo comentários sobre a violência institucional, Cunha, Pinto e Souza (2019, p. 2156) explicam que:

A violência institucional, uma das grandes novidades da Lei n. 13431/2017, é aquela praticada por instituição pública ou conveniada que pode inclusive gerar a revitimização. Esse conceito respalda a definição de violência institucional apresentada pelo art. $5^{\circ}$, I, do Decreto n. 9603/2018: "violência praticada por agente público no desempenho de função pública, em instituição de qualquer natureza, por meio de atos comissivos ou omissivos que prejudiquem o atendimento à criança ou ao adolescente vítima ou testemunha de violência". Se a rede de proteção do menor, ao interagir com este, não observar os protocolos, as normas e a especialidade do atendimento devido à pessoa em desenvolvimento, ela pode provocar sérios danos a esse menor.

Complementado essa abordagem, os autores mencionados trazem, ainda, as subdivisões existentes no conceito do termo compreendido por vitimização, o qual possui três dimensões, conforme segue:

a) vitimização primária: decorre direta e imediatamente da prática do crime; b) vitimização secundária (ou revitimização): deriva mediatamente do crime, quando a vítima tem que resgatar o contexto de violência de que fora vítima para auxiliar na persecução penal do agressor; c) vitimização terciária: procede do meio social, que estigma o indivíduo em razão de ele ter sido vítima de determinado tipo de crime.

$\mathrm{O}$ artigo $5^{\circ}$ da Lei 13.431/17 preza por estabelecer garantias e direitos inerentes às crianças e adolescentes. No inciso I, do dispositivo mencionado, tem-se a previsão de que crianças e adolescentes são dignos de prioridade absoluta e reconhecimento da condição peculiar de pessoa em desenvolvimento. Nesse sentido Digiácomo e Digiácomo (2018, p. 24) dizem que "[...] não basta atender primeiro, mas sim é preciso atender melhor, e embora a coleta de evidências da violência praticada seja importante, o bem-estar da criança/adolescente vítima ou testemunha vem em primeiro lugar".

Isso significa que, apesar de ser a criança ou adolescente vítima ou testemunha de violência o detentor dos maiores indícios de materialidade e autoria das violências sofridas, quando essa questão estiver em contraposta com o desconforto da criança ou jovem em falar sobre o assunto, deverá prevalecer o bem-estar deles em detrimento da colheita de provas invasiva, que pode, não raramente, ocasionar na revitimização (Cunha; Pinto \& Souza, 2019).

Por isso, "[...] se a inquirição do menor sobre a situação de violência lhe ocasionar prejuízo insuportável, a prova que se pretende deve ser produzida por outra maneira que não a sua oitiva" (Cunha; Pinto \& Souza, 2019).

Não obstante a inovação normativa consistente na previsão legal da violência institucional, não se pode olvidar da violência estabelecida no inciso III do artigo $4^{\circ}$ da Lei 13.431/2017, qual seja a violência sexual, que será explanada na sequência, até aprofundar-se naquela estabelecida na alínea a, onde está prevista a forma de violência sexual cometida mediante abuso sexual.

A Organização Mundial da Saúde (OMS) conceitua violência sexual como sendo o ato sexual, insinuação sexual indesejada, ou, ainda, a mera tentativa de uma dessas hipóteses, assim como ações que visem lucrar ou se utilizar da sexualidade de um sujeito mediante coerção praticada por uma outra pessoa, mesmo que não haja vínculo entre elas, podendo ocorrer em âmbito residencial, ou onde a vítima exerce suas atividades laborais.

De acordo com as colocações de Cunha (2019, p. 503), o Código Penal, no seu Título VI, com o advento da Lei 12.015/09, deixou de tutelar os crimes contra os costumes e passou a utilizar-se da terminologia dos crimes contra a dignidade sexual, pois consoante o autor entende-se como a "expressão umbilicalmente ligada à liberdade e ao desenvolvimento sexual da pessoa humana."

Em uma análise já em âmbito de criança e adolescente, de acordo com Florentino (2015, p. 139): 
[...] a violência sexual, caracteriza-se por atos praticados com finalidade sexual que, por serem lesivos ao corpo e a mente do sujeito violado (crianças e adolescentes), desrespeitam os direitos e as garantias individuais como liberdade, respeito e dignidade previstos na Lei no 8.069/90 - Estatuto da Criança e do Adolescente (Brasil, 1990, Artigos 7º 15, 16, 17 e 19).

A violência sexual pode acarretar inúmeros danos à integridade física e psicológica das vítimas, e em níveis devastadores. Enquadradas no rol das consequências físicas e de incidência imediata, tem-se a ocorrência de gravidez, contágio por doenças sexualmente transmissíveis (DST), ou infecções no aparelho reprodutor. Já sobre os danos com efeito a longo prazo, há os distúrbios ginecológicos. Destaca-se, também, a possibilidade dessa conduta desencadear problemas psiquiátricos, como por exemplo, dependência de drogas, depressão, crises de pânico, somatização ou tentativa de suicídio, em face da condição de instabilidade que passa a viver a vítima (Facuri et al., 2013).

Observa-se que o conceito de violência sexual, devido a sua amplitude, pode ser subdividido em exploração sexual e abuso sexual, sendo este último enfoque do presente trabalho.

Pertinente a exploração sexual, compreende-se como sendo a relação sexual envolvendo criança ou adolescente com um adulto, visando lucro, vantagens ou permutas. Consoante a Childhood, as principais formas são as seguintes:

A pornografia se configura como exploração sexual quando há produção, utilização, exibição, comercialização de material (fotos, vídeos, desenhos) com cenas de sexo explicito envolvendo crianças e adolescentes ou imagem, com conotação sexual, das partes genitais de uma criança. O tráfico para fins sexuais é a prática que envolve cooptação e/ou aliciamento, rapto, intercâmbio, transferência e hospedagem da pessoa recrutada para essa finalidade. $\mathrm{O}$ mais recorrente é que o tráfico para fins de exploração sexual ocorra de forma disfarçada por agências de modelos, turismo, trabalho internacional, namoro-matrimônio, e, mais raramente, por agências de adoção internacional. A exploração sexual agenciada é quando há a intermediação por uma ou mais pessoas ou serviços. No primeiro caso as pessoas são chamadas rufiões, cafetões e cafetinas e, no segundo, os serviços são normalmente conhecidos como bordéis, serviços de acompanhamento, clubes noturnos. A exploração sexual não-agenciada é a prática de atos sexuais realizada por crianças e adolescentes mediante pagamento ou troca de um bem, droga ou serviço.

Na concepção de Cunha $(2019,536)$, pode-se entender por exploração sexual como sendo:

[...] uma dominação e abuso do corpo de crianças, adolescentes e adultos (oferta), por exploradores sexuais (mercadores), organizados, muitas vezes, em rede de comercialização local e global (mercado), ou por pais ou responsáveis, e por consumidores de serviços sexuais pagos (demanda).

Ainda, o mesmo autor, expõe as quatro categorias por ele entendidas como prática de exploração sexual, as quais seguem:

a) prostituição - atividade na qual atos sexuais são negociados em troca de pagamento não apenas monetário;

b) turismo sexual - é o comércio sexual, bem articulado, em cidades turísticas, envolvendo turistas nacionais, estrangeiros e principalmente mulheres e jovens, de setores excluídos de Países de Terceiro Mundo;

c) pornografia - produção, exibição, distribuição, venda, compra, posse e utilização de material pornográfico, presente também na literatura, cinema, propaganda etc.; e

d) tráfico para fins sexuais - movimento clandestino e ilícito de pessoas através de fronteiras nacionais, com o objetivo de forçar mulheres e adolescentes a entrar em situações sexualmente opressoras e exploradoras, para lucro dos aliciadores, traficantes. (Cunha, 2019)

No que concerne à prática do abuso sexual em sentido amplo, conduta penalmente criminalizada por meio do crime de estupro previsto no artigo 213 do Código Penal, Cunha (2019, p.504-505) alerta que:

Tutela-se a dignidade sexual da vítima, constrangida mediante violência ou grave ameaça. $\mathrm{O}$ vocábulo estupro, no 
Brasil, se limitava a incriminar o constrangimento de mulher à conjunção carnal. Outros atos libidinosos estavam tipificados no artigo seguinte, que protegia, também o homem. Resolveu o legislador, com a edição da Lei 12.015/2009, seguir a sistemática de outros países (México, Argentina e Portugal), reunindo os dois crimes num só tipo penal, gerando, desse modo, uma nova acepção ao vocábulo estupro, hoje significando não apenas conjunção carnal violenta, contra homem ou mulher (estupro em sentido estrito), mas também o comportamento de obrigar a vítima, homem ou mulher, a praticar ou permitir que com o agente se pratique outro ato libidinoso.

Ademais, abre-se destaque ao fator relevante que, diante da tamanha gravidade dos crimes de abuso sexual, seja o previsto no artigo 213 do Código Penal, seja o disposto no 217A, do mesmo diploma legal, estupro de vulneráveis (menores de 14 anos ou pessoa com ausência do discernimento necessário à prática do ato), a Lei dos Crimes Hediondos, 8.072/90, agravou suas penas, por considerar as condutas hediondas, fazendo com que constassem no rol do artigo $1^{\circ}$, nos incisos V e VI.

Em relação ao abuso sexual infantil, a Organização Mundial da Saúde (OMS) (2003, apud Moraes, 2015, p.9) explica que:

[...] é todo envolvimento de uma criança em uma atividade sexual na qual não compreende completamente, já que não está preparada em termos de seu desenvolvimento. Não entendendo a situação, a criança, por conseguinte, torna-se incapaz de informar seu consentimento. São também aqueles atos que violam leis ou tabus sociais em uma determinada sociedade. O abuso sexual infantil é evidenciado pela atividade entre uma criança com um adulto ou entre uma criança com outra criança ou adolescente que pela idade ou nível de desenvolvimento está em uma relação de responsabilidade, confiança ou poder com a criança abusada. É qualquer ato que pretende gratificar ou satisfazer as necessidades sexuais de outra pessoa, incluindo indução ou coerção de uma criança para engajar-se em qualquer atividade sexual ilegal.

Complementando a definição anterior, é compreendido, também, por abuso sexual:

[...] qualquer contato, ato ou jogo sexual, envolvendo relação hetero ou homossexual, em que o agressor esteja em estágio de desenvolvimento psicossexual mais adiantado que a criança ou adolescente. O agressor pode se impor pela força, por ameaça ou indução da vontade da vítima; esta pode ser estimulada sexualmente ou servir de estímulo sexual para o agressor. Pode variar desde abusos sem contato sexual (voyeurismo, exibicionismo, pornografia, indução à prostituição) até atos sem penetração (sexo oral, intercurso interfemural) ou com penetração (digital, com objetos, intercurso genital ou anal). (Assis \& Constantino, 2001).

Outro aspecto importante a salientar, é que o abuso sexual contra crianças e adolescentes pode acontecer em ambiente familiar, ou não. Essas duas situações podem ser conceituadas por abuso sexual intrafamiliar e abuso sexual extrafamiliar, respectivamente.

Quanto ao primeiro caso, os autores dos abusos sexuais são pessoas que contam com laços afetivos e relação consanguínea com as vítimas. Essa prática também é conhecida por incesto, e por não serem raros os casos em que os abusos são acobertados pelos demais componentes do núcleo familiar, possui continuidade delitiva que se estende por anos e, portanto, acarretando danos incalculáveis nas vítimas.

Por outro lado, o abuso sexual extrafamiliar é aquele perpetrado por sujeito que não possui qualquer parentesco com a vítima (Florentino, 2015). Na concepção de De Antoni et al. (2010, [s. p].):

Geralmente é ocasionado por um adulto sem laços parentais e que pode ser conhecido ou não da família. Sempre é aludido àquelas crianças e adolescentes que vivem em situação de rua, e geralmente está relacionado à exploração sexual comercial, como podemos observar em materiais divulgados por programas governamentais de combate à exploração sexual.

Denota-se que nos casos de abuso sexual intrafamiliar, por conta de proximidade do convívio diário, essas disfunções são ainda mais acentuadas. Do mesmo modo, os danos que resultam das relações de abuso intrafamiliar são, de certa forma, 
mais marcantes, justamente por serem atos que ferem a dignidade das vítimas, entretanto cometidos, em tese, pelo grupo social que deveria conferir-lhes proteção, cuidado e amparo enquanto na condição de crianças e adolescentes.

Ainda com relação a esse tipo de violência, o abuso sexual de modo analítico, registra três níveis de disfunção, sendo eles: o poder que o abusador emprega sobre a criança e adolescente, a confiança que a vítima deposita no abusador, visto por ela como protetor e a si como sua dependente, e a aplicação de forma vexatória da sexualidade, que infringe o direito de dignidade humana da vítima, uma vez que não respeita seu corpo. (Habigzang \& Caminha, 2004)

Sobre o tema, Rossato, Lépore e Sanches (2014, p.145) adicionam que:

No Brasil, apesar de ainda insuficiente, existe um movimento muito importante no sentido de combater essa nefasta prática, na esteira da indignação da comunidade internacional de defesa dos direitos humanos daquelas pessoas, principalmente pela situação de vulnerabilidade e pela dificuldade encontrada para a reversão do processo traumatizante ocasionado.

Em nota sobre o abuso sexual, o Conselho Nacional de Justiça elaborou um quadro comparativo, onde constam verdades e mitos envolvendo o abuso sexual contra o público infanto-juvenil. É o que se confere na literalidade da ilustração da Figura 1: 
Figura 1. Mitos e Verdades sobre o abuso sexual contra menores.

\begin{tabular}{|c|c|}
\hline MITOS & VERDADES \\
\hline $\begin{array}{l}66 \text { Crianças possuem imaginaçăo fertil. } \\
\text { Por isso, quando se queixam de abuso } \\
\text { sexual, estăo fantasiando." }\end{array}$ & $\begin{array}{l}\text { Embora fatores como a imaginaçāo e o desen- } \\
\text { volvimento psiquico incompleto da criança } \\
\text { sejam considerados em um processo judicial, } \\
\text { isso năo significa que faitem com a verdade. A } \\
\text { palavra da vitima è sempre relevante na apu- } \\
\text { raçấo desses crimes, o o depoimento sera } \\
\text { considerado pelo juiz, assim como outros ele- } \\
\text { mentos apresentados. }\end{array}$ \\
\hline $\begin{array}{l}66 \text { Se abuso for verdadeiro, criança } \\
\text { lembrará tempo, a duraçăo ou } \\
\text { o lugar por longo tempo." }\end{array}$ & $\begin{array}{l}\text { Crianças năo registram na memória tempo, } \\
\text { duraçầo ou lugar como os adultos. }\end{array}$ \\
\hline $\begin{array}{l}66 \text { É fácil reconhecer o abusador: } \\
\text { normalmente é pobre, visivelmente } \\
\text { perturbado e "mal-encarado" }\end{array}$ & $\begin{array}{l}\text { Crianças não registram na memória tempo. } \\
\text { duraçẫo ou lugar como os adultos. }\end{array}$ \\
\hline $\begin{array}{l}66 \text { o abusador é sempre do } \\
\text { sexo masculino." }\end{array}$ & $\begin{array}{l}\text { Mulheres também podem cometer abusos } \\
\text { sexuais. }\end{array}$ \\
\hline $\begin{array}{l}\text { 66 abusador é sempre um } \\
\text { desconhecido." }\end{array}$ & $\begin{array}{l}\text { Mais de } 50 \% \text { dos abusos săo cometidos } \\
\text { por membros da familia, e cerca de } 80 \% \\
\text { dos abusadores são pessoas conhecidas } \\
\text { das crianças. }\end{array}$ \\
\hline $\begin{array}{l}66 \text { Somente meninas são vitimas de } \\
\text { abuso sexual." }\end{array}$ & Um terço das vitimas é do sexo masculino. \\
\hline $\begin{array}{l}66 \text { Todo pedófilo foi abusado } \\
\text { na infância." }\end{array}$ & Pode ter acontecido, mas nem sempre. \\
\hline 66 obusador é sempre homossexual." & $\begin{array}{l}\text { Adultos homossexuais nâo abusam mais } \\
\text { de crianças do que heterossexuais. }\end{array}$ \\
\hline 66 Pedófilos sāo incuráveis." & $\begin{array}{l}\text { Embora não se possa falar de cura, necessi- } \\
\text { tam de tratamento para prevenir novos casos } \\
\text { ou evitar que o abuso venha a ocorrer. }\end{array}$ \\
\hline
\end{tabular}

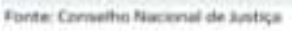

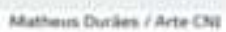

Fonte: Conselho Nacional de Justiça (2017).

Do exposto acima, extrai-se que muito embora exista a tipificação do crime relacionado ao abuso sexual, e considerada como hedionda a conduta abusiva praticada contra crianças e adolescentes, a sociedade, em geral, sustenta "mitos" culturais impregnados pelo senso comum, tanto que, para tentar amenizá-los, em pleno ano de 2017, fizeram-se necessárias publicações e reportagens no sentido de ampliar a sensibilidade e a visão em prol de crianças e jovens que comunicam crimes dessa natureza.

Como demonstrado no quadro anterior, é preciso desmistificar a ideia de que a criança em razão da sua imaginação fértil "não sabe o que está falando", pois não consegue indicar local dos abusos ou quem era o agressor, e por conta disso, suas alegações são "coisa da cabeça” dela, uma vez que são características razoáveis diante de suas cognições, que se diferenciam das de um adulto nos quesitos de tempo e memória. Tendo isso em vista, as declarações de crianças e jovens serão consideradas em âmbito processual, em observância aos direitos e garantias que ostentam, bem como em total consonância aos demais elementos probatórios constantes nos autos do processo. 
Feito isso, após perpassar pelos fatores históricos ligados ao público infanto-juvenil, seus avanços no alcance de direitos e garantias, bem como explicadas algumas formas de violências que podem ofender-lhes a dignidade, e dentre elas a de liberdade sexual, bandeia-se para a averiguação da ocorrência de casos dessa natureza, mas restritas àqueles envolvendo abuso sexual contra vítimas crianças ou adolescentes, na Comarca de Júlio de Castilhos - RS.

\section{Análise de dados e das incidências de atendimentos realizados no município de Júlio de Castilhos/RS: A necessidade de} implementação de protocolos e fluxogramas destinados à Crianças e Adolescentes vítimas de abuso sexual

Em pesquisa elaborada junto ao Poder Judiciário, mais especificamente na Comarca de Júlio de Castilhos, Vara Judicial, foram observados os aspectos que seguem expostos em gráficos, retirados de um total de 23 processos analisados, pois realizadas as buscas somente nos autos disponíveis em cartório e excluídos os remetidos ao Tribunal de Justiça para apreciação de recursos, em razão da ausência de tempo hábil para retorno dos processos e posterior análise. Além disso, salienta-se que os processos examinados contemplam fatos que aconteceram durante o período compreendido entre o dia 19 de outubro de 2002 (Processo distribuído somente em 2018), sendo esse registro da data do fato o mais antigo deles, até meados de setembro de 2018, registro de ocorrência de fato mais recente, dentre os autos analisados.

A partir dos dados coletados, percebe-se que entre as crianças e adolescentes vítimas de abuso sexual na Comarca de Júlio de Castilhos, predominam as do sexo feminino, consoante informação do Gráfico 1:

Gráfico 1: Sexo das vítimas.

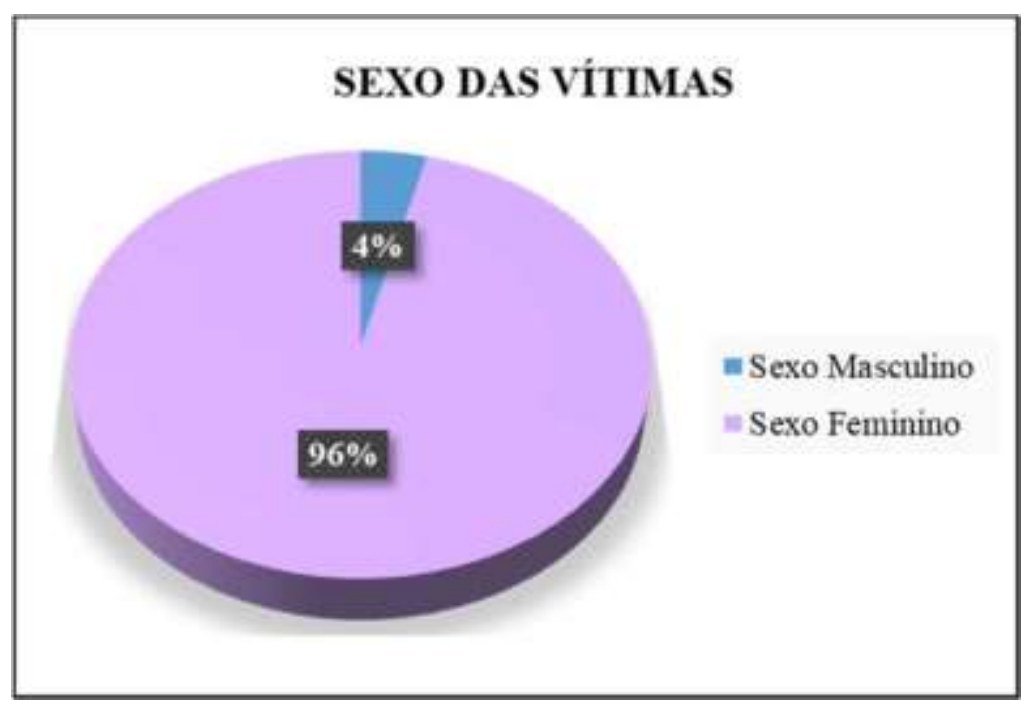

Fonte: Elaborado pelos pesquisadores (2019).

Relativamente a idade das vítimas, apurou-se que, em sua maioria, possuíam 13 anos na época dos abusos. Assim demonstra o Gráfico 2: 
Gráfico 2: Relação de idade das vítimas.

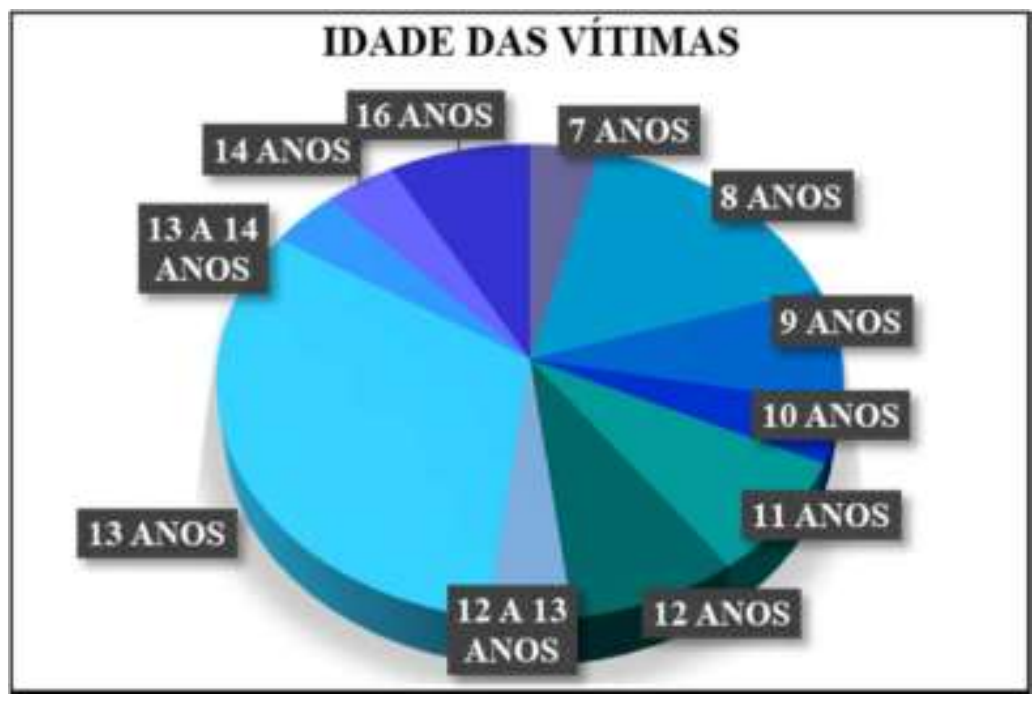

Fonte: Elaborado pelos pesquisadores (2019).

Para fins elucidativos, dividindo-se os casos analisados entre aqueles de abuso extrafamiliar e abuso intrafamiliar, apurou-se que os cometidos dentro da seara doméstica e familiar comportam $70 \%$ dos acontecimentos. Nesse sentido, segue o Gráfico 3:

Gráfico 3: Relação de convívio.

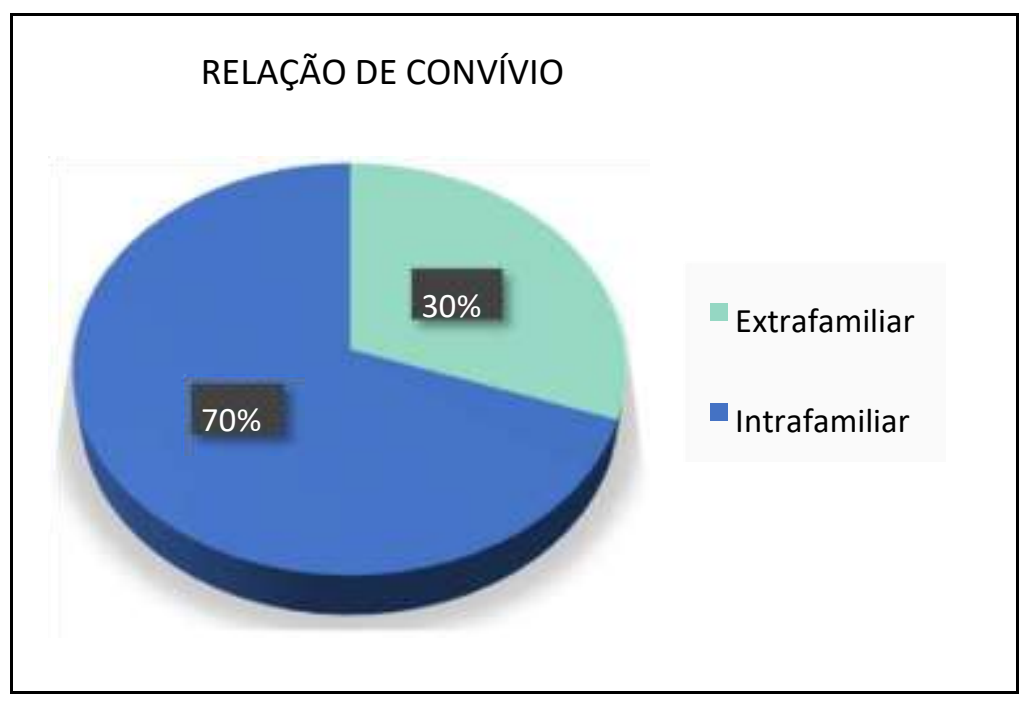

Fonte: Elaborado pelos pesquisadores (2019).

Nesse âmbito, de ocorrência de abuso sexual contra vítima que faz parte do próprio núcleo familiar do abusador, conforme dados colhidos durante a pesquisa, constatou-se que $32 \%$ delas são enteadas dos autores do delito, enquanto que, quase alcançando esses índices, têm-se a ocorrência de vítimas que sofreram abusos sexual por parte de seus companheiros, conceito onde foram introduzidos aqueles considerados como, companheiros (união estável), "namorados" e "ficantes". Desse modo, segue o Gráfico 4: 
Gráfico 4: Relação Intrafamiliar.

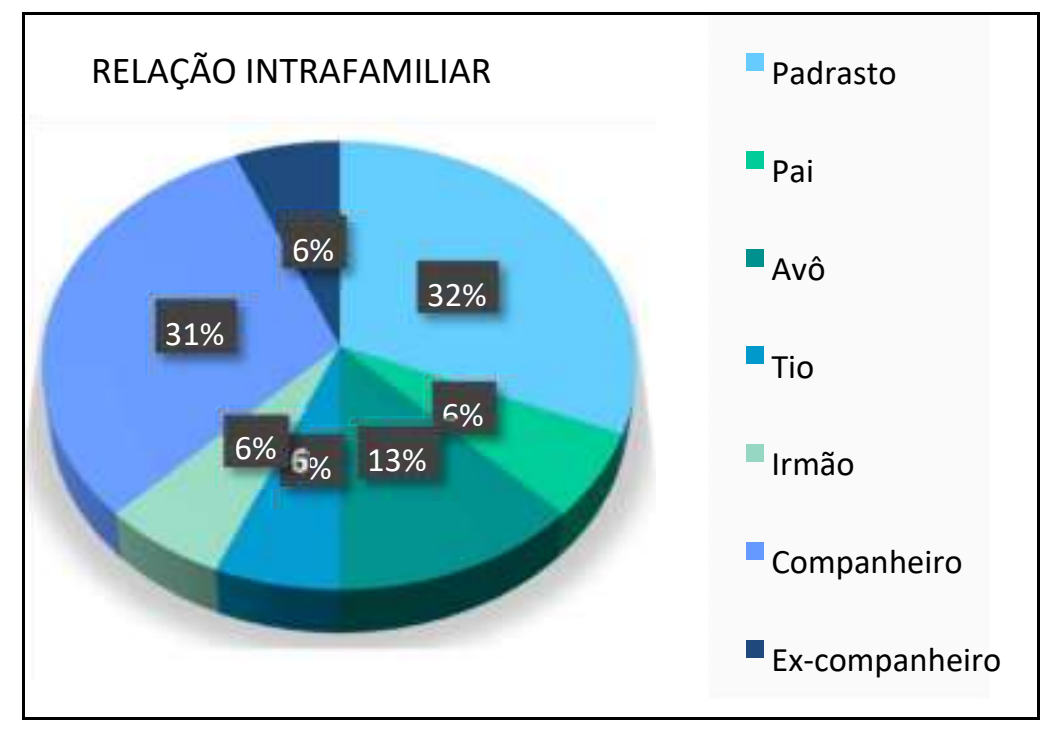

Fonte: Elaborado pelos pesquisadores (2019).

Além disso, considerando os dados para fins de localização, uma vez que a Comarca de Júlio de Castilhos abrange os Municípios de Júlio de Castilhos/RS e Pinhal Grande/RS, verificou-se que 78\% dos casos, reprisa-se, daqueles analisados em cartório, ocorreram na Cidade de Júlio de Castilhos, enquanto que o restante, 22\%, no Município de Pinhal Grande, Cidade contígua. Assim ilustra o Gráfico 5:

Gráfico 5: Local de ocorrência.

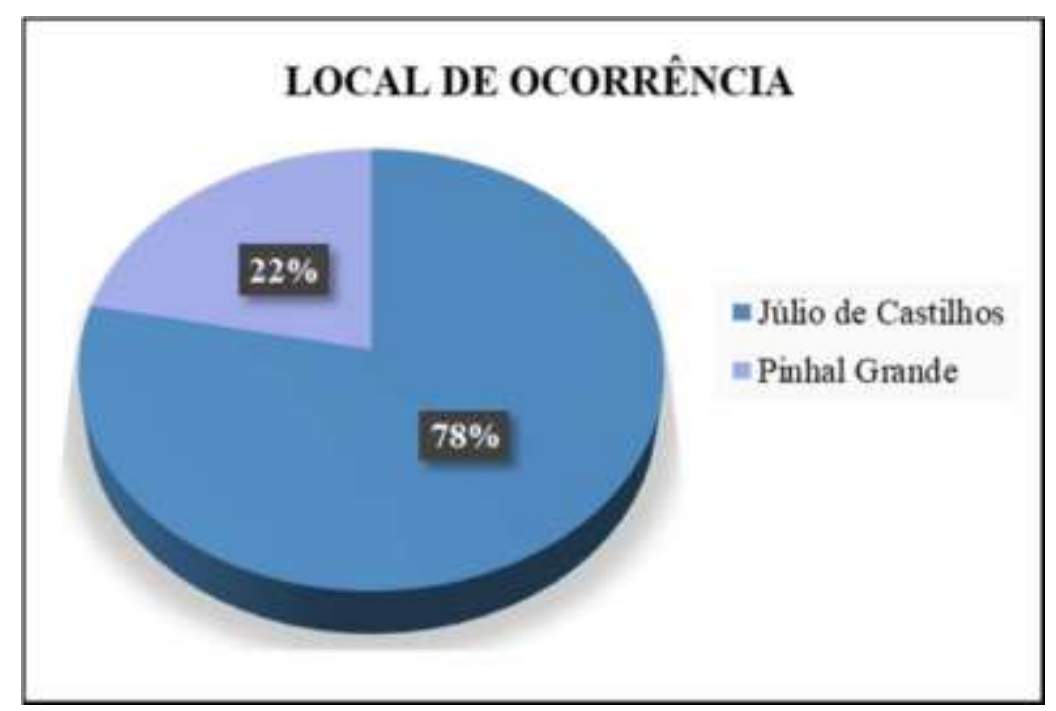

Fonte: Elaborado pelos pesquisadores (2019).

O Órgão que mais recebeu a denúncia da prática de abuso sexual envolvendo crianças e adolescentes foi a Delegacia de Polícia, o que se resume em 57\% dos primeiros registros dos casos. Sustentando essa informação, traz-se o Gráfico 6 : 
Gráfico 6: Comunicação inicial do fato.

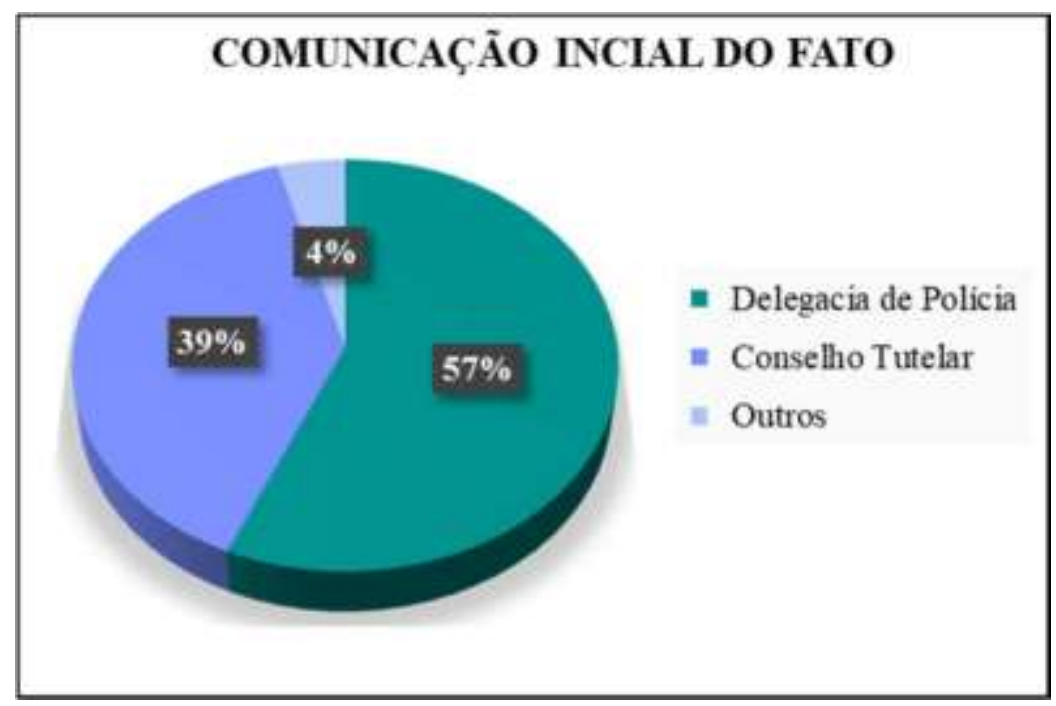

Fonte: Elaborado pelos pesquisadores (2019).

Relativamente à prestação de atendimento psicossocial às vítimas dos casos examinados, averiguou-se que cerca de 57\% dos casos tiveram acesso a esse modelo de atendimento. Tais dados constam no Gráfico 7:

Gráfico 7: Realização de atendimentos psicossociais.

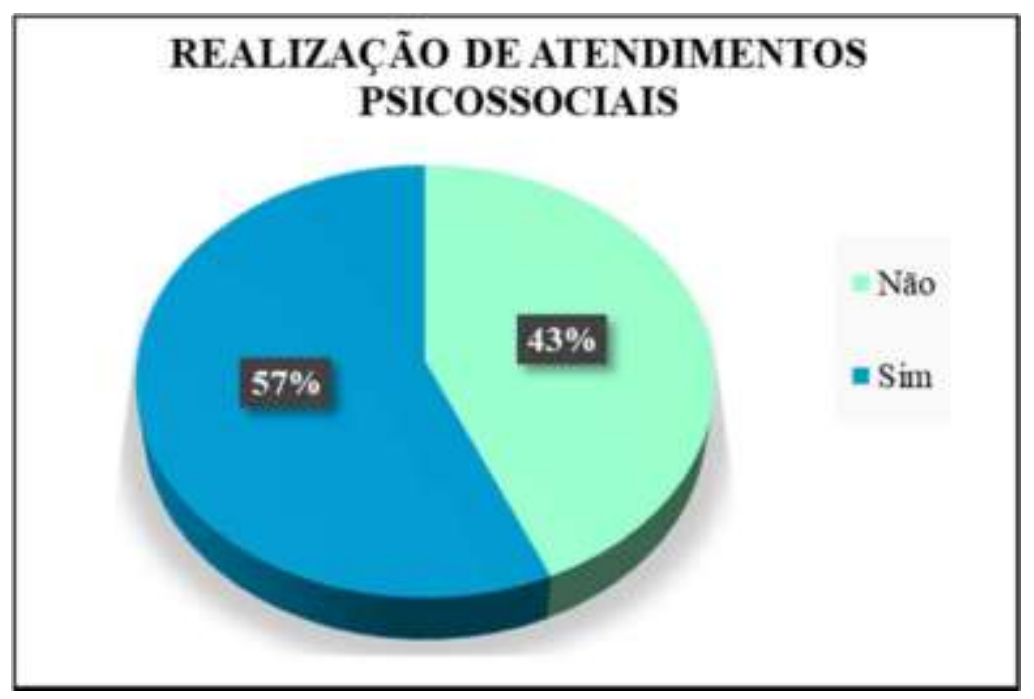

Fonte: Elaborado pelos pesquisadores (2019).

Desse percentual, a instituição que mais realizou o atendimento foi o CREAS, veja-se o Gráfico 8: 
Gráfico 8: Sexo das vítimas.

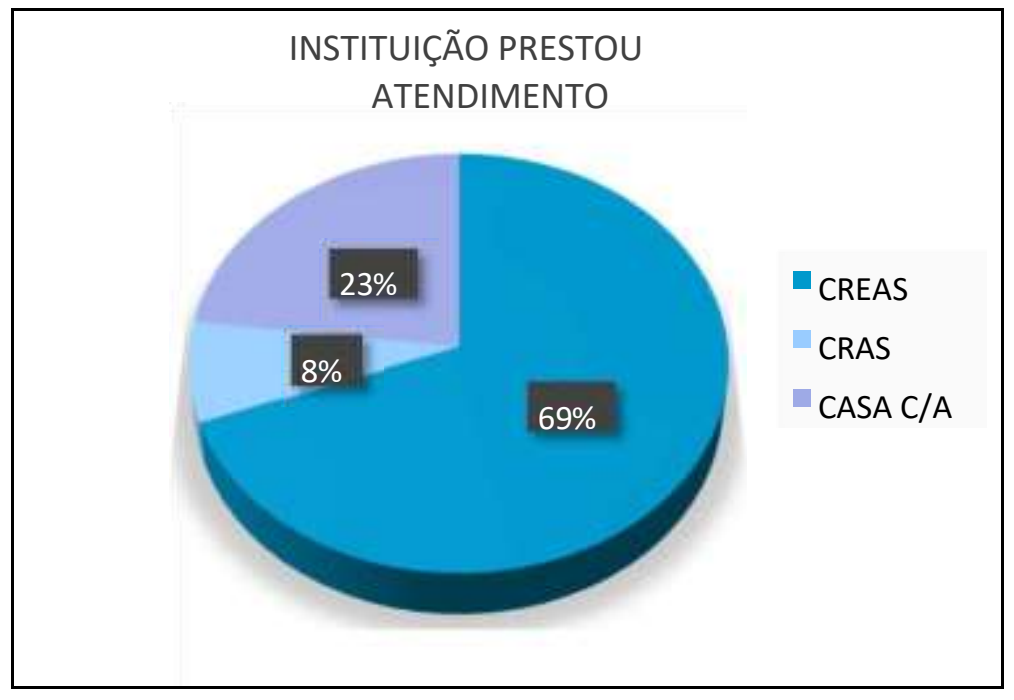

Fonte: Elaborado pelos pesquisadores (2019).

Diante da exposição gráfica, abre-se destaque ao dado mais relevante da pesquisa para o presente artigo, qual seja, aquele que pretendeu apurar em quantas das situações estudadas as vítimas receberam atendimento psicossocial. Transferindo essa informação para porcentagem, devidamente ilustrada, verificou-se que em 57\% dos casos houve efetivo acesso ao atendimento psicossocial.

Todavia, apesar de se ultrapassar a metade dos números, esse cômputo está longe de alcançar os ideais estabelecidos na legislação que trata dos direitos de crianças e adolescentes, pois, segundo o padrão a ser estabelecido, toda criança ou adolescente vítima de qualquer violência tem direito a ser encaminhada para tratamento psicossocial.

Ademais, faz-se necessário pontuar uma peculiaridade que deparou-se durante o estudo: não há menção sobre a continuidade da prestação do atendimento. Isto é, não foi possível identificar qual o período que as vítimas estavam submetidas aos atendimentos necessários, ficando aparentemente demonstrado que os atendimentos (exceto os casos de acolhimento institucional, onde haviam mais de um relatório de atendimento, em geral, do CREAS) foram fornecidos apenas a título de constatação do abuso sexual para fins de persecução penal.

Eventualmente, considera-se a possibilidade da instituição prestadora do atendimento ter dado continuidade ao caso, de acordo com sua convicção, porém, frisa-se novamente, não constam nos autos documentos informando o início e o término dos atendimentos, mesmo naqueles casos onde já há sentença, ou seja, encaminhados para a "reta final" da ação penal, o que não rara as vezes levam-se anos, períodos que apesar de distante da época do fato, ainda justificam a necessidade do constante fornecimento de atendimentos.

Destaca-se, ainda, que a realização da pesquisa foi feita a nível de Judiciário, a fim de constatar como esse Poder tem atuado frente as determinações legais envolvendo crianças e adolescentes.

Enfatiza-se esses aspectos, relacionados ao ainda elevado índice de casos sem atendimentos, pois, na óptica de Faleiros (2003, p. 69), em decorrência das relações de abuso sofridas pelas vítimas, sobrevêm tramas que acabam se transformando em dramas. Esses dramas fazem-se atuar diretamente em questões pertinentes às relações sociais. Assim, gerase o trauma, o qual desencadeia sofrimento, descarte de possibilidades ou falta de confiança e análise de si próprio. Essas marcas podem ser identificadas por meio da raiva ou de vestígios psicossomáticos. Todavia, possuem distinções se comparados os sintomas de uma pessoa com outra.

Diante dessas razões, despertou-se certa preocupação nas organizações destinadas aos interesses de crianças e 
adolescentes, que buscaram alternativas para amenizar todo o impacto avassalador que os traumas causavam nos jovens e no público infantil e juvenil, incluindo-se nisso a fase que é necessário realizar a denúncia e expor as condutas criminosas sofridas, bem como a passagem pelos atendimentos, os quais seguem após a etapa dos relatos.

Por isso, a Resolução n. ${ }^{\circ}$ 169, de 13 de novembro de 2014, do Conselho Nacional dos Direitos da Criança e do Adolescente (CONANDA), trabalhou nesse sentido e dispôs, em suma, que o público infanto-juvenil quando em atendimentos psicossociais perante os órgãos públicos seria ouvido em total conformidade com o sistema de garantia de direitos consagrados pela Constituição Federal e pelo Estatuto da Criança e do Adolescente, sendo atendidos por equipe profissional multidisciplinar competente para realizar a tarefa, em número de componentes suficientes para a demanda, e que zelasse pelo respeito às crianças e adolescentes, e na mesma seara, observasse estritamente os princípios relacionados com a dignidade humana dessas crianças e jovens. Isso, levando-se sempre em consideração os sofrimentos psíquicos a que essas crianças e jovens foram sujeitados durante suas trajetórias como vítimas de qualquer tipo de violência, até se depararem com o auxílio de um profissional, conforme artigo $2^{\circ}, \S 2^{\circ}$ do documento referido.

Na mesma linha e intencionando os mesmos objetivos acima relatados, foi criada a Lei 13.341/2017, visando garantir direitos às crianças e adolescente vítimas ou testemunhas de violência, dando ênfase à criação de mecanismos de atendimentos e acentuando a necessidade de aperfeiçoamento dos que já existiam, determinando como se procederão o depoimento especial e a escuta especializada. (Digiácomo \& Digiácomo, 2018). Dissertam nesse aspecto dos Santos e Coimbra (2017, p. 596):

[...]as propostas e práticas para a tomada de depoimento de crianças e adolescentes giram em torno dos seguintes itens: que ocorra uma única vez; o mais cedo possível; em sala diferenciada e pelo intermédio de profissionais capacitados - principalmente psicólogos ou assistentes sociais - a fim de que sejam feitas perguntas de forma mais adequada ao depoente.

Ainda no âmbito da referida Lei, no artigo 27, foi concedido aos Estados, Distrito Federal e aos Municípios, a obrigação de legislarem sobre o sistema que busca implementar (de garantias de direitos às crianças e jovens vítimas de violências), no prazo concedido, qual seja, 180 dias, contados da sua vacatio legis.

Com isso, é possível observar a grande responsabilidade confiada aos entes municipais, pois é notório que por seus agentes estarem inteirados das suas realidades sociais locais e, portanto, de suas carências também, saberão como normatizar, a exemplo, um protocolo de atendimento destinado às crianças e aos adolescentes vítimas de abuso sexual, que interligue a rede de apoio, os órgãos que deverão realizar os atendimentos, e o público infanto-juvenil, de forma eficiente.

Ressalta-se a importância dessa legislação, que almejou a todo o momento alcançar os padrões do princípio da proteção integral da criança e do adolescente, ao dedicar a estes normas e regras específicas em seus benefícios, pois além de garantir que as vítimas de qualquer tipo de violência serão ouvidas o menor número de vezes possível e tipificar a violência institucional em casos de violação dessa diretriz, estabeleceu no artigo 11, caput e $\S 1^{\circ}$, I e II , a implementação do rito cautelar de antecipação da prova judicial quando a vítima contar com idade inferior a 7 anos ou em caso de violência sexual, permitindo, em face do curto lapso temporal entre a data de ocorrência dos abusos e a colheita do depoimento, maior fidelidade quando da exposição dos fatos e redução do índice de alterações dos eventos no relato, acarretando, assim, maior veracidade ao depoimento prestado, o que contribui para a persecução penal e provável condenação do abusador na seara criminal, sem causar ou aumentar danos às vítimas, como ocorre com a prática da revitimização (Digiácomo \& Digiácomo, 2018).

Todavia, segundo pesquisa realizada no endereço virtual da Prefeitura de Júlio de Castilhos/RS, mais especificamente no campo de publicações das Leis, com o intuito de verificar se o Município conta com alguma legislação nesse sentido (de observância aos preceitos da Lei 13.431/17), foi aferido que não há legislação versando sobre tema, até o presente momento.

De todo modo, enfatiza-se que tal inobservância, acaba por prejudicar àqueles que carecem dos atendimentos de 
forma interdisciplinar e intersetorial, o que claramente ficou demonstrado que não está ocorrendo, pois os dados colhidos junto ao Poder Judiciário indicam que são, consideravelmente, baixos (apenas 57\% receberam atendimentos), além disso, o Município de Júlio de Castilhos/RS, não legislou sobre os protocolos e fluxogramas de atendimentos de crianças vítimas de violência, tampouco há publicação anunciando a destinação de verbas à políticas públicas a serem desenvolvidas para crianças e adolescentes, consoante dispõe o princípio da prioridade absoluta.

A falta de um protocolo com o fluxo de atendimento impede que seja ofertado o cuidado e a atenção necessária para lidar com os casos envolvendo crianças e adolescentes vítimas de violências, visto que nas situações analisadas a oferta dos serviços vem se mostrando precária, ou seja, as vítimas não têm sido acolhidas e atendidas pelos órgãos responsáveis em sua integralidade, além de ser constatado que o atendimento, na grande maioria das vezes, não é realizado de forma periódica e durável. Esse atendimento fragmentado, por vezes, sem chegar a conhecimento de todos os profissionais que compõem a rede de proteção ao público infatojuvenil, faz com que o atendimento não seja adequado prejudicando de forma direta a vítima de violência, sem falar, que isso pode caracterizar uma violência institucional.

Ante as pontuações, denota-se a importância da elaboração de fluxograma para casos semelhantes aos analisados, pensando numa forma de lograr êxito na normatização da prestação de atendimentos psicossocias, através da rede de apoio integralizada, os pesquisadores confeccionaram um possível protocolo de atendimento, ante a ausência de uma proposta elaborada município, como forma de representar como vem ocorrendo os atendimentos. Passe-se a ser demonstrada conforme o Fluxograma 1:

Fluxograma 1: Atendimento à criança e ao adolescente vítima de violência sexual.

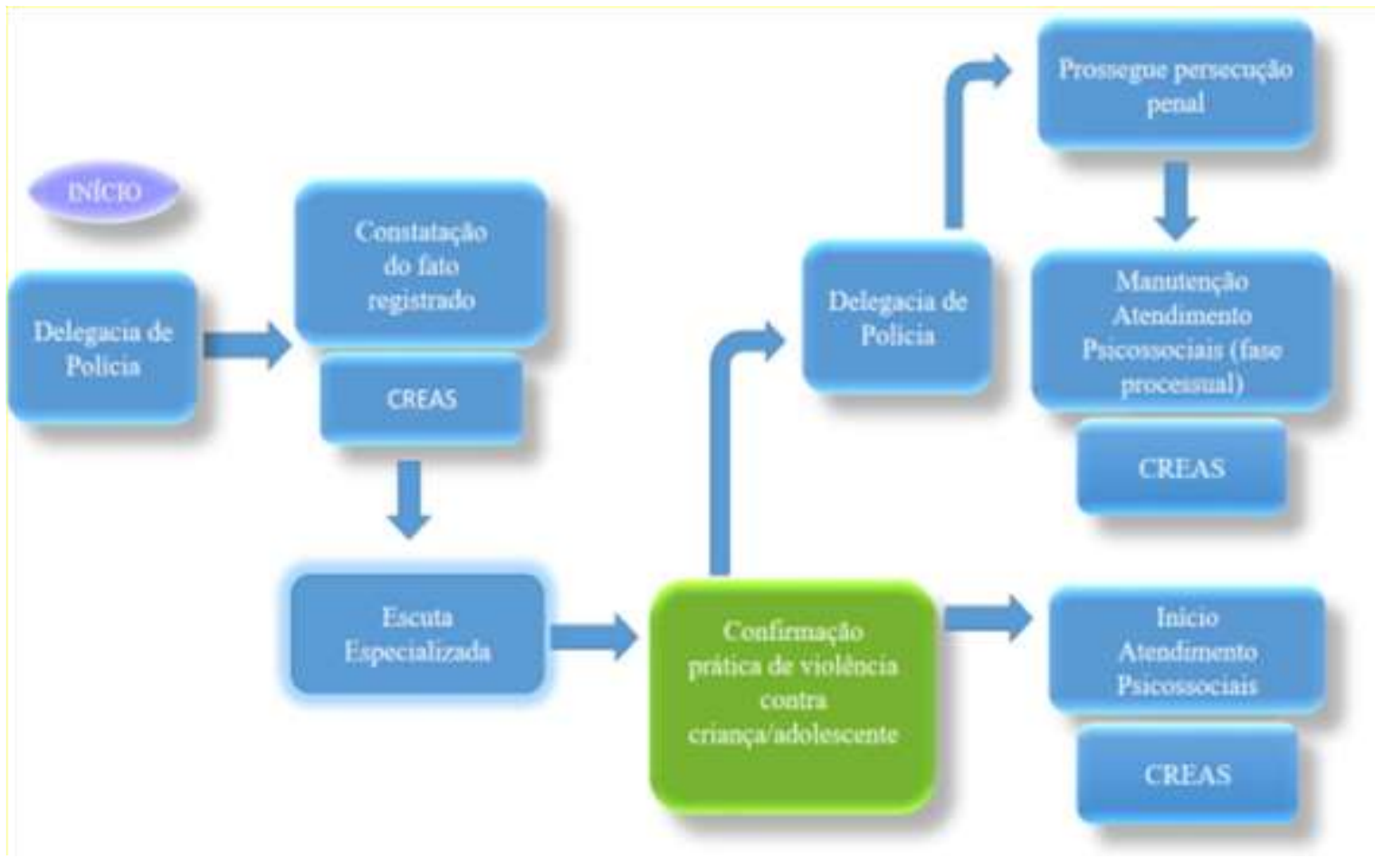

Fonte: Elaborado pelos pesquisadores (2019).

Do fluxograma supra, elaborado com base nas informações retiradas da pesquisa feita nos processos da Comarca de Júlio de Castilhos, considerando que a Delegacia de Polícia foi o órgão que mais recebeu as denúncias de casos envolvendo crianças e adolescentes como vítima de abuso sexual considerou-se como sendo a "porta de entrada" para o percurso até o efetivo atendimento. Desse modo, tendo em vista o primeiro contato com a vítima, a autoridade policial responsável por elaborar documento solicita o encaminhamento da criança ou adolescente para o Centro de Referência Especializada de 
Assistência Social (CREAS) de Júlio de Castilhos, pois foi à instituição mais presente nos casos analisados. Recebida a vítima para sua primeira oitiva, em atenção aos preceitos da Lei 13.431/17, procede-se as Escutas Especializadas das crianças ou adolescentes, a fim de verificar a constatação de abuso sexual. Confirmada a ocorrência do abuso, as vítimas foram encaminhadas para iniciar o atendimento, com profissionais especializados em suas respectivas áreas na temática envolvendo violência sexual. Concomitantemente, instruindo a investigação, com os indícios mínimos de materialidade do crime demonstrados pela Escuta Especializada, a autoridade policial encaminha o expediente ao Ministério Público, para opinio delict, e finalmente chega até o Poder Judiciário.

Destaca-se que, durante todo esse trâmite, os atendimentos devem ser constantes, pois são necessários diante da gravidade dos danos e traumas que o crime de abuso sexual causa nas vítimas, especialmente nas crianças e adolescentes.

Ressalta-se que o padrão apresentado, é de caráter meramente explicativo, uma vez que com a realização da pesquisa foi possível verificar a não implementação dessa prática no Município de Júlio de Castilhos/RS, resultado que apontou a não padronização dos atendimentos dos casos, tanto antes quanto após a Lei 13.431/17 entrar vigor, motivo pelo qual foi elaborado o modelo de acordo com os casos "comuns" de ocorrência, pois foram esses os maiores índices nas pesquisas realizadas, devendo-se ter sempre em mente que cada caso possui as suas particularidades e merecendo atenção, também, os aspectos relativos a saúde da criança ou adolescente, onde, sendo preciso, ela deverá ser diretamente encaminhada para atendimento médico hospitalar, sem entretanto, esquecer-se do atendimento psicológico.

Todavia, percebe-se que a questão da violência é extremamente complexa, havendo a necessidade da participação de todos os profissionais que compõem o sistema de garantias de direitos devendo haver um processo de articulaçao permanente $\mathrm{e}$ coletiva, assim, para a elaboração de um protocolo de atendimento é imprescindível a participação de toda a rede que integra esse grupo intersetorial.

Por fim, constata-se a importância de se ter em todos os municípios do país protocolos de atendimentos, haja vista que se os fluxos forem adequadamente compreendidos por todos os que compõem a rede de proteção, a rigor os prejuízos com a saúde, desenvolvimento físico e psicológico, poderão ser minimizados o máximo possível para as crianças e adolescentes.

\section{Considerações Finais}

A violência praticada contra crianças e adolescentes não é um problema atual e não resta de dúvida ser um dos maiores problemas sociais que assola a população infantojuvenil.

A Constituição Federal de 1988, o Estatuto da Criança e do Adolescente, além de demais leis infraconstitucionais dispõem sobre os direitos da criança e do adolescentes e, enfatizam a proteção integral, que deve ser assegurado pela família, pelo Estado e pela sociedade. Todavia, percebe-se que esse direito por vezes é ameaçado pela violência. Além disso, por serem pessoas em estágio de desenvolvimento são mais vulneráveis e consequentemente mais frequentes alvos de situações de violência.

A negligência, as violências física, psicológica, sexual são alguns dos tipos de violências sofridas pela população infatojuvenil. Por isso há muito a se fazer, visto que em muitos casos os atendimentos não têm sido realizados de forma humanizada e acolhedora, podendo em alguns casos ensejar a violência institucional.

Ante as questões levantadas é que a pesquisa desenvolvida foi de suma importância e, dessa forma, possibilitou concluir que não há aplicação das disposições legais previstas na Lei 13.431/17 no Município de Júlio de Castilhos/RS.

Conforme mencionado anteriormente, foram analisados 23 processos na Comarca de Júlio de Castilhos/RS, os quais envolviam crianças e adolescentes vítimas de estupro. Por meio desse levantamento buscou-se demonstrar o déficit no que se refere à efetiva prestação de atendimentos psicossociais para tais vítimas, bem como, verificar se o Município estava a par das novidades legislativas, colocando crianças e adolescentes com prioridade absoluta diante da destinação de verbas públicas para 
instituir programas de atendimentos, após serem vítimas de violência.

Dessa forma, diante da inobservância da legislação que preza pela implementação de protocolos de atendimentos de crianças e adolescentes, denota-se que se tornam precárias a apuração dos índices, que poderiam auxiliar, através das informações, um fluxograma mais detalhado e especificado, ou seja, eficaz.

Ressalta-se, também, que apesar de não diminuir os traumas e dramas, pois o fato já ocorreu quando a criança ou adolescente carece de atendimento, esses serviços são vistos como alternativa para reduzir esses danos psicológicos. Por isso, é importante que sejam efetivados. Porém, isso somente é possível se respeitado o princípio da prioridade absoluta na predestinação das verbas públicas em favor do público infantojuvenil, o que ficou demonstrado que não é observado no Município de Júlio de Castilhos, conforme apontou a pesquisa feita na legislação municipal.

Em tese, confirma-se a hipótese levantada na pesquisa, porém verifica-se que a forma de ocorrência não se assemelha daquela considerada a ideal, pois ainda há avanços a serem conquistados na prática, como a agilidade de encaminhamento de todas as vítimas de abuso sexual para atendimento psicossocial, e a manutenção delas ao longo da instrução processual. Outra forma que poderia auxiliar a alcançar esses objetivos seria o Ministério Público, ao receber o inquérito policial de apuração do abuso sexual, constatando que a Delegacia de Polícia assim não fez, requeresse ao Poder Judiciário, junto ao oferecimento da denúncia, o encaminhamento da vítima ao CREAS para passar a receber atendimento, imediatamente, pois já se está diante de uma fase avançada para recém iniciar-se essa prática, a qual, de forma ideal, deve ocorrer já no instante do primeiro relato da criança e do adolescente sobre como ocorreu o abuso sexual por eles sofrido. Assim, acolhendo o pedido do Ministério Público, a autoridade judiciária encaminha a vítima para o atendimento. Não observado isso pelo MP, pode o juiz, em último caso, requerer o início do atendimento, ao receber a denúncia, como meio de agilizar esse processo.

Além disso, conforme a pesquisa processual verificou-se que em $43 \%$ dos casos as vítimas não foram encaminhadas para atendimentos psicossociais, por nenhum dos legitimados mencionados, restando como meros figurantes na fase processual, onde se amplia a visão para analisar minuciosamente quesitos que envolvem mais o abusador do que a criança ou o adolescente que foi abusada sexualmente, o que não se deve aceitar em um Estado Democrático de Direito que prevê inúmeros direitos e garantias para as crianças e adolescentes, inclusive por meio de um Estatuto próprio, mas que, infelizmente, acabam por serem inobservados em meio ao cumprimento de prazos processuais.

A partir das análises levantadas percebemos a pertinência da temática na comunidade local, restando claro a necessidade de novas pesquisas na Comarca de Júlio de Castilhos, a fim de verificar se neste período de pandemia houve algum desamparo as crianças ou adolescentes, principalmente em vista do isolamento social ser momento, em tese, propicio a um agravamento dos casos de abusos sexuais infantojuvenis. Além do mais, seria de suma importância averiguar se houve alguma ação por parte do Poder Público Municipal a fim de garantir o cumprimento integral da Lei. 13.431/2017, que determina a implementação do protocolo de atendimento destinado a crianças e adolescentes vítimas da referida violência.

\section{Referências}

Amim, A. R., Santos, A. M. S., Moraes. B. M., \& Maciel. K. R. F. L. A. (2017). Curso de direito da criança e do adolescente: aspectos teóricos e práticos. 1(10). Saraiva.

Antoni, C. (2011). Abuso sexual extra familiar: percepções das mães de vítimas. Estud. psicol. Campinas. 28(1), 97-106. http://www.scielo.br/scielo.php?script=sci_arttext\&pid=S0103166X2011000100010\&lng=en\&nrm=iso.

Assis, S. G., \& Constantino, P. (2001). A vitimização sexual. In: Filhas do mundo: infração juvenil feminina no Rio de Janeiro [online]. (pp. 123-133). FIOCRUZ. https://static.scielo.org/scielobooks/vjcdj/pdf/assis-9788575413234.pdf.

Brasil. Conselho Nacional de Justiça. (2017). CNJ Serviço: mitos e verdades do depoimento especial de crianças. http://www.cnj.jus.br/noticias/cnj/85491cnjservico-mito-e-verdade-do-depoimento-especial-de-criancas.

Brasil. (1988). Constituição da República Federativa do Brasil. http://www.planalto.gov.br/ccivil_03/constituicao/constituicaocompilado.htm. 
Brasil. (1927). Decreto $\mathrm{n}^{\mathrm{o}}$ 17.943. Consolida as leis de assistência e proteção a $e$ mores. http://www.planalto.gov.br/ccivil_03/decreto/19101929/D17943A.htm.

Brasil. (1979). Lei nº 6.697. Institui o Código de Menores. http://www.planalto.gov.br/ccivil_03/_Ato2015-2018/2017/Lei/L13431.htm.

Brasil. (1990). Lei $\mathrm{n}^{\circ}$ 8.069. Dispõe sobre o Estatuto da Criança $e$ do Adolescente $e$ dá outras providências. http://www.planalto.gov.br/ccivil_03/LEIS/L8069.htm.

Brasil. (2017). Lei $\mathrm{n}^{\circ}$ 13.431. Estabelece o sistema de garantia de direitos da criança e do adolescente vítima ou testemunha de violência e altera a Lei no 8.069, de 13 de julho de 1990 (Estatuto da Criança e do Adolescente). http://www.planalto.gov.br/ccivil_03/_Ato2015-2018/2017/Lei/L13431.htm.

Brasil. Ministério da Saúde. (2018). Organização Mundial da Saúde - OMS. OMS aborda consequências da violência sexual para saúde das mulheres. https://nacoesunidas.org/oms-aborda-consequencias-da-violencia-sexual-para-saude-dasmulheres/.

Brasil. Ministério da Justiça. (2014). Conselho Nacional dos Direitos da Criança e do Adolescente - CONANDA. Resolução N. ${ }^{\circ}$ 169. http://www.direitosdacrianca.gov.br/conanda/resolucoes/169-resolucao-169-de-13-denovembro-de-2014/view.

Childhood Brasil. (2013). Entenda a diferença entre abuso e exploração sexual. https://www.childhood.org.br/entenda-a-diferenca-entre-abuso-e-exploracaosexual.

Cunha, R. S. (2019). Leis penais especiais: comentadas artigo por artigo. 1(2). JusPODIVM.

Cunha, R. S. (2019). Manual de direito penal: parte especial (arts. 121 ao 361). 1(11). JusPODIVM.

Digiácomo, M. J., \& Digiácomo, E. (2018). Comentários à Lei $n^{o} \quad$ 13.431/2017. Ministério Público do Paraná. http://www.crianca.mppr.mp.br/arquivos/File/publi/caopca/lei_13431_comentada_jun2018. Pdf.

Facuri, C. O. (2013). Violência sexual: estudo descritivo sobre as vítimas e o atendimento em um serviço universitário de referência no Estado de São Paulo, Brasil. Cad. Saúde Pública. 29(5), 889-98. http://www.scielo.br/scielo.php?script=sci_arttext\&pid=S0102-311X2013000500008\&lng=en\&nrm=iso.

Faleiros, V. P. (2003). Abuso sexual de crianças e adolescentes: trama, drama e trauma. Serv. Soc. \& Saúde. 2(1), 65-82.

Ferreira, L. A. M., \& Doi, C. T. (2018). A proteção integral das crianças e dos adolescentes vítimas. http://www.crianca.mppr.mp.br/pagina1222.html.

Florentino, B. R. B. (2015). As possíveis consequências do abuso sexual praticado contra crianças e adolescentes. Fractal, Rev. Psicol. 27(2), 139-144. http://www.scielo.br/scielo.php?script=sci_arttext\&pid=S198402922015000200139\&lng=pt\&nrm=iso.

Fundo das Nações Unidas para a Infância - Unicef. (2018). A cada 7 minutos, uma criança ou um adolescente morre vítima da violência. https://www.unicef.org/brazil/pt/media_37371.html.

Gonçalves, C. (2012). Direito Civil Brasileiro: Parte Geral. 1(10). Saraiva.

Habigzang, L. F., \& Caminha, R. M. (2004). Abuso sexual contra crianças e adolescentes: conceituação e intervenção clínica. 1. Casa do Psicólogo. https://www.passeidireto.com/arquivo/39436762/habigzang-caminha-2004-abuso-sexual-contra-criancas-e-adolescentes-conceituacao.

Ishida, V. K. (2019). Estatuto da Criança e do Adolescente: Doutrina e Jurisprudência. 1(20). JusPODIVM.

Maia, C. C. M. (2018). No limite do progresso. Proteção e Direitos da criança e do adolescente. http://www.conjur.com.br/2010-abr-08/doutrinaprotecaointegral-direitos-crianca-adolescente.

Minayo, M. C. S. (1983). Quantitativo-Qualitativo: oposição ou complementaridade. Cadernos de Saúde Pública. 9(3), 239-62.

Moraes, G. M. (2015). Abuso Sexual Infantil E Pedofilia: Perspectivas Psicológicas, Aspectos Penais E Sanções Controversas. Monografia final de curso de Bacharel em Direito - Universidade Federal de Santa Maria, 1-61.

Neri, C., \& Oliveira, L. C. (2010). A doutrina da situação irregular e a doutrina da proteção integral: infância e adolescência sob controle e proteção do estado. http://cacphp.unioeste.br/eventos/iisimposioeducacao/anais/trabalhos/221.pdf.

Perez, J. R. R., \& Passone, E. F. (2010). Políticas sociais de atendimento às crianças e adolescentes no Brasil. Cad. Pesqui. 40(140), 649-673. http://www.scielo.br/scielo.php?script=sci_arttext\&pid=S010015742010000200017\&lng=en\&nrm=iso.

Popper, K. S. (1975). A lógica da pesquisa científica. 1(2). Cultrix.

Ramborger, L. R. (2015). As consequências do descumprimento das obrigações inerentes ao poder familiar e a intervenção do Estado. Trabalho de Conclusão de Curso de Bacharel em Direito - Universidade de Cruz Alta, 1-33.

Rossato, L. A., Lépore, P. E., \& Cunha, R. S. (2014). Estatuto da criança e do adolescente comentado artigo por artigo. 1(6). Revista dos Tribunais.

Santos, A. R., \& Coimbra, J. C. (2017). O Depoimento Judicial de Crianças e Adolescentes entre Apoio e Inquirição. Psicol. cienc. prof., 37(3), 595-607. http://www.scielo.br/scielo.php?script=sci_arttext\&pid=S141498932017000300595\&lng=pt\&nrm=iso.

Vargas, R. (2015). Princípio do melhor interesse da criança e do adolescente nos processos de família. Monografia final de curso de Bacharel em Direito Universidade Regional do Noroeste do Estado do Rio Grande Do Sul, 1-70. 